\title{
新しい有機合成 酸・塩基複合反応剤の知見と展望
}

\section{大 嶌 幸一郎*・野 崎}

\author{
New Organic Synthesis
}

_ Findings and Outlooks of Combined Acid-Base Reagents -

Koichiro Oshima* and Hitosi NozaKI*

Synthetically useful reactions mediated by reagents containing aluminum as a key atom are disclosed. The reagents perform combined acid-base attack on substrates with less activation energies. The aluminum Lewis acid center serves to bind the substrate and subsequently the base directly attached to aluminum is excited by the coordination and attacks the substrate in the following rateand product-determining step. Supports of this idea as well as extensions are described.

\section{1. はじめに}

酸・塩基複合反応剂の概念については前稿で解説し た ${ }^{1)}$ 。ここではその後に見いだされた二, 三の新事実を 中心に, 背景, 意義, 今後の発展への夢といったものを 述べて，ご批判を仰ぎたい。なおここに述べる機構論的 論議は証拠に乏しく作業仮説の域を脱しないものである ことをまずお断りしておく。

本稿を草するに当って向山光昭教授の総説 ${ }^{2)}$ をいつ か再読した。そしてわれわれの考えと共通点があまりに も多いことにあらためて驚いた次第である。併読くださ るよう颃願いする。

主な話題は $\mathrm{R}_{3} \mathrm{Al}$ または $\mathrm{R}_{2} \mathrm{AlX}\left(\mathrm{X}=\mathrm{OAr}, \mathrm{SBu}^{\mathrm{t}}\right.$, $\mathrm{SPh}, \mathrm{NR}^{1} \mathrm{R}^{2}$, I など) で示される反応剂の挙動である。 $\mathrm{R}_{2} \mathrm{AlX}$ はもちろん Lewis 酸である。基質をとりこんで 錯体を形成する。しかし基質の $\mathrm{n}$-電子対が $\mathrm{Al}$ にとりこ まれると，それまで $\mathrm{Al}$ の電子久捐を中和していた $-\mathrm{X}:$ の $\mathrm{n}$ 電子対は目をさます。そして基質に対し求核剤つま り塩基としての攻撃をおこす。Alで基質をつかまえて おいて，Xで吒くというのだからこの塩基の攻撃はたい へん有効である。そしてXによる求核攻撃が生成物を決

\section{* 京都大学工学部工業化学教室}

* Department of Industrial Chemistry, Faculty of Engineering, Kyoto University(
める律速段階になる。基質を $\mathrm{Al}$ がとらえる過程はたん に速い平衡とみられる場合が多い。でもそうした能力の ない反応剂たとえば $\mathrm{LiNR}^{1} \mathrm{R}^{2}$ と $\mathrm{Et}_{2} \mathrm{AlNR}^{1} \mathrm{R}^{2}$ とをくら べると, 後者の方がはるかに有効な反応剤である。呼び 込み役の効能は大きい。だからこういった反応剂を酸・ 塩基複合反応剂と呼ぼうというわけである。一種のミニ ミニ酵素といった性格を備えている。触媒的にまわらな いのが残念だが，この種の反応剂ならほんのわずかの 「無機合成」で作り出すことができ, 高選択性を発揮さ せ得る。反応剤のデザインが反応そのもののデザインに つけ加わって, 有機合成の可能性を倍加させるものであ る。そして実用的な効果も多い。有機合成屋は長い間, 棚の無機薬品をそのまま使って仕事してきた。そろそろ 反応剂を自分の気に入るように設計, 製作して実用する。 そんな時代にさしかかっているのではないだろうか。

2. リン酸アリルエステルと $\mathrm{R}_{2} \mathrm{~A} I \mathrm{X}$ との反応, “へキサン中の SN2"反応

式（1）はアリルについたリン酸エステルが OAr, $\mathrm{SR}, \mathrm{SAr}, \mathrm{NHPh}$ などに高収率で置換される反応であ る $^{3)}$ 。この反応は立体特異的に進み二重結合に何の影響 もおよばさない。

$$
\begin{gathered}
\mathrm{RMeC}=\mathrm{CHCH}_{2}-\stackrel{\mathrm{O}}{\stackrel{\mathrm{OP}}{\mathrm{O}}(\mathrm{OEt})_{2}} \\
\stackrel{\mathrm{Me}_{2} \mathrm{AlX}}{\text { hexane }} \mathrm{RMeC}=\mathrm{CHCH}_{2}-\mathrm{X}
\end{gathered}
$$




\begin{tabular}{|c|c|c|c|c|}
\hline \multirow{2}{*}{ Reagent } & \multirow{2}{*}{ Substrate } & \multirow{2}{*}{$\begin{array}{l}\text { Conditions } \\
(\mathrm{h}),\left({ }^{\circ} \mathrm{C}\right)\end{array}$} & \multicolumn{2}{|c|}{ Product } \\
\hline & & & $\mathrm{x}$ & Y (\%) \\
\hline $\mathrm{Me}_{2} \mathrm{AlSBu}^{t}$ & Geranyl & $0.5,0$ & $\mathrm{SBu}^{t}$ & 97 \\
\hline $\mathrm{Me}_{2} \mathrm{AlSBu}^{t}$ & Neryl & $0.5,0$ & $\mathrm{SBu}^{t}$ & 92 \\
\hline $\mathrm{Me}_{2} \mathrm{AlSPh}$ & Neryl & $0.5,0$ & $\mathrm{SPh}$ & 83 \\
\hline $\mathrm{Me}_{2} \mathrm{AlNHPh}$ & Geranyl & $0.5,0 ; 12,20$ & $\mathrm{NHPh}$ & 74 \\
\hline $\mathrm{Me}_{2} \mathrm{AlNHPh}$ & Neryl & $0.5,0 ; 12,20$ & $\mathrm{NHPh}$ & 82 \\
\hline $\mathrm{Me}_{2} \mathrm{AlOPh}$ & Geranyl & $0.3,0 ; 1.5,20$ & $\mathrm{OPh}$ & 85 \\
\hline $\mathrm{Me}_{2} \mathrm{AlOPh}$ & Neryl & $0.3,0 ; 1,20$ & $\mathrm{OPh}$ & 77 \\
\hline
\end{tabular}

このへキサン中でのイオン反応をより樑く理解するた めに, カルベオールのリン酸エステルをとりあげて置換 反応の立体化学を検討した ${ }^{4)}$ 。式 (2) に示すように, シスのエステルからはトランス置換体が, トランス異性 体からはシス体がそれぞれほぼ選択的に得られる。さら に $\alpha$ 位での置換体 $\left(\mathrm{S}_{\mathrm{N}} 2\right)$ と $\gamma$ 位での置換体 $\left(\mathrm{S}_{\mathrm{N}} 2^{\prime}\right)$ の 比はほぼ 4:1である。式 (1) のゲラニオール, ネロー

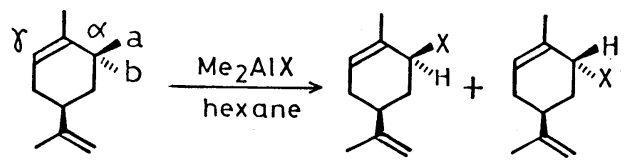

cis-I $\mathrm{a}=\mathrm{OPO}(\mathrm{OEt})_{2} \quad \mathrm{~b}=\mathrm{H}(\mathrm{D}) \quad$ cis $-\Pi \mathrm{a}, \mathrm{b}, \mathrm{c}$ trans $-\Pi \mathrm{a}, \mathrm{b}, \mathrm{c}$ trans $-\mathrm{I} \quad \mathrm{a}=\mathrm{H}, \mathrm{b}=\mathrm{O}-\mathrm{PO}(\mathrm{OEt})_{2}$ a : $\mathrm{X}=\mathrm{OPh}, \mathrm{b}: \mathrm{X}=\mathrm{SPh}$,

c : $\mathrm{X}=\mathrm{NHPh}$

\begin{tabular}{l|l|l|l|l}
\hline \multirow{2}{*}{ Substrate } & \multirow{2}{*}{$\begin{array}{c}\text { Reagent } \\
\mathrm{X}\end{array}$} & \multirow{2}{*}{$\mathrm{Y}(\%)$} & \multicolumn{2}{|c}{ Product II } \\
\cline { 4 - 5 } & $\mathrm{N}$ & & cis (\%) & trans (\%) \\
\hline cis-I & $\mathrm{OPh}$ & 80 & 2 & $98(84 / 16)$ \\
cis-I & $\mathrm{SPh}$ & 92 & 3 & $97(60 / 40)$ \\
cis-I & $\mathrm{NHPh}$ & 70 & 12 & $88(76 / 24)$ \\
trans-I & $\mathrm{OPh}$ & 86 & $89(90 / 10)$ & 11 \\
trans-I & $\mathrm{SPh}$ & 94 & $90(76 / 24)$ & 10 \\
trans-I & $\mathrm{NHPh}$ & 87 & $99(82 / 18)$ & 1 \\
\hline
\end{tabular}

The data in parentheses indicate $\alpha / \gamma$ ratio for the predominant isomer.

ルの場合には二重結合の配置は保持され位置異性体も認 められない。この式 (1) では一級炭素と三級炭素との 競争であるのに対し, 式 (2) のカルベオール体では反 応点がともに二級炭素であり遊離アリル陽イオンであれ ば選択性が期待できないはずである。

まず $\mathrm{P}=\mathrm{O}$ 酸素に $\mathrm{Al}$ が配位する。この配位体は式 （3）の共鳴式で示される。式の右側は限りなく緊密な

$$
\begin{aligned}
& \mathrm{Sub}-\mathrm{OP}(\mathrm{OEt})_{2}=\mathrm{O} \rightarrow \mathrm{Al}(\mathrm{Et})_{2}-\mathrm{OPh} \\
& \longleftrightarrow \mathrm{Sub}^{\oplus} \stackrel{*}{\mathrm{O}}=\mathrm{P}(\mathrm{OEt})_{2}-\stackrel{*}{\mathrm{O}}-\mathrm{Al}^{\ominus}(\mathrm{Et})_{2}-\stackrel{*}{\mathrm{O} P h}
\end{aligned}
$$

イオン対に相当する。その陰イオン部は負荷電を強く非 局在化する構造をもっている。式中 $\mathrm{O} *$ は負荷電をとり うる。ヘキサン分子の弾性衝突をくり返しているらちに, リン酸エステル部よりもより強い求核性をもつ塩基部分
$\mathrm{OPh}$ が陽イオン部へ動く。この際単一のイオン対を考 えると $\mathrm{S}_{\mathrm{N}} \mathrm{i}$ 型の配置保持の反応が認められそうである が，実際には上述のとおり背面からの攻撃により $\mathrm{S}_{\mathrm{N}} 2$ 型 の反転がおこる。溶媒かご内の単一イオン対ではなく式 （4）に示すように何分子も会合した集合体での反応と 考えている。
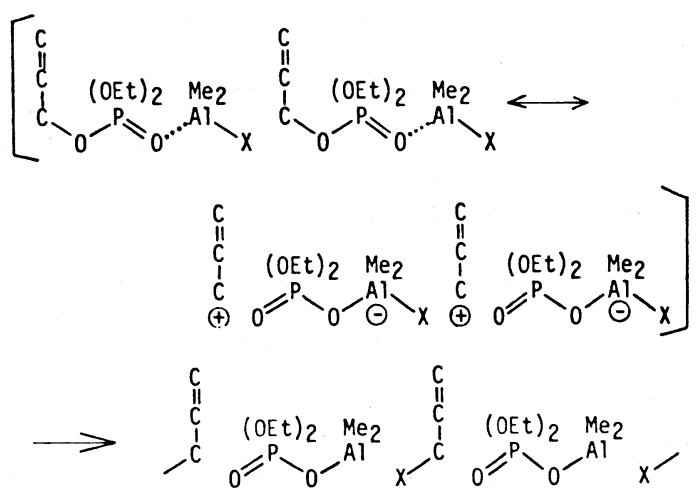

ヘキサン以外の溶媒では反応混合物は均一な溶液である のに対し，へキサン中では反応の前後とも白色の懸濁液 状のままである。この事実が他の溶媒系での反応結果と の大きな相違を示唆しているのかもしれない。反応速度 と反応温度との関係を調べれば証拠が得られるかもしれ ないが, 今後の課題である。

ゲラニオール，ネロールでは Sub甲部分は全然姿をか えずに置換される。三級炭素と一級炭素では求核攻撃に 対する容易さが相当違うためであろう。むしろカルベオ ールの場合に, もとリン酸エステル脱離基のついていた 場所での置換反応がかなり優先する事実の方が注目に価 する。イオン対の陽イオン部が十分遊離の形にはないこ とを示している。

溶媒をへキサンから極性の高いものにとりかえた場合 の結果を式（5）に示す。溶媒の極性があがると集合体

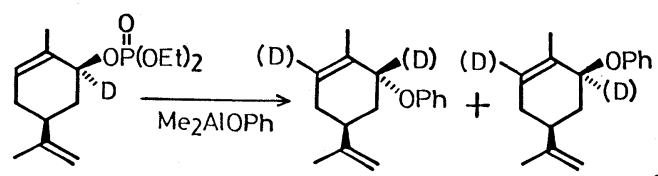

Solvent effect on the substitution

\begin{tabular}{l|c|c|c}
\hline \multicolumn{1}{c|}{ Solvent } & Yield $(\%)$ & trans $(\alpha / \gamma)$ & cis $(\alpha / \gamma)$ \\
\hline hexane & 80 & $98(84 / 16)$ & 2 \\
$\mathrm{CH}_{2} \mathrm{Cl}_{2}$ & 70 & $76(74 / 26)$ & $24(71 / 29)$ \\
$\mathrm{Et}_{2} \mathrm{O}$ & 79 & $87(75 / 25)$ & $13(77 / 23)$ \\
$\mathrm{DME}$ & 82 & $57(63 / 37)$ & $43(63 / 37)$ \\
$\mathrm{THF}$ & 91 & $25(60 / 40)$ & $75(63 / 37)$ \\
\hline
\end{tabular}


の会合度の低下とともに，イオン対の密着もそれだけ解 かれることになる。会合度の減少によりかご内単一イオ ン対の反応が増えることになり，その結果 $\mathrm{S}_{\mathrm{N}} \mathrm{i}$ あるいは $\mathrm{S}_{\mathrm{N}} \mathrm{i}^{\prime}$ 型の反応が見られるようになるのであろう。イオン 対の密着のゆるみは陽イオン部の自由度に反映される。 アリル陽イオンの対称化が進み $\alpha$ 位置換体と $r$ 位置換 体の比が $1: 1$ に近づくものと考えられる。実際 $\mathrm{Et}_{2} \mathrm{O}$, DME, THF の順に立体保持の割合は増し, THF の場合 に保持率は $75 \%$ にも達する。 $\mathrm{Al}$ に対する配位能の大 きい THF が集合体の形成を妨げ，単一イオン対形成に 有利に㗢らくためであろう。 $\alpha / \gamma$ の比も $60 ： 40$ となり陽 イオン部はかなりの自由度を獲得していることを示す。

“ヘキサン中での $\mathrm{SN} 2$ 型反応” はアリルアルコールに 限らずふつうの二級アルコールのメシラートにおいても 認められる。式（6）に示すように反転生成物が高い選 択性をもって生成する。

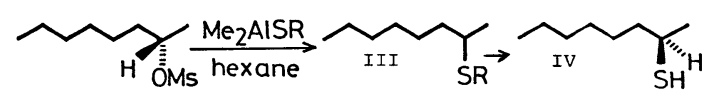

\begin{tabular}{c|c|c|c|c}
\hline $\mathrm{R}$ & Cond. & $\begin{array}{c}\text { Yield } \\
\text { of III } \\
(\%)\end{array}$ & $\begin{array}{c}{[\alpha]_{\mathrm{D}}^{20} \text { of III }} \\
\text { in benzene }\end{array}$ & $\begin{array}{c}{[\alpha]_{\mathrm{D}}^{20} \text { of IV }} \\
\text { in abs. EtOH }\end{array}$ \\
\hline $\mathrm{COCH}_{3}$ & $0^{\circ} \mathrm{C} \quad 2 \mathrm{~h}$ & 86 & $+6.0^{\circ}(\mathrm{c} 1.5)$ & $-30.8^{\circ}(\mathrm{c} 1.2)$ \\
$\mathrm{CH}_{2} \mathrm{Ph}$ & $25^{\circ} \mathrm{C} 25 \mathrm{~h}$ & 59 & $-16.5^{\circ}$ (c 1.7$)$ & $-32.2^{\circ}$ (c 1.1$)$ \\
\hline$[\alpha]_{\mathrm{D}}^{20}-32.8^{\circ}$ (c 1.48 , abs. EtOH) has been reported for
\end{tabular}
the optically pure $(\mathrm{R})-(-)-2$-octanethiol.

\section{3. リン酸および酢酸のアリルエステルと $\mathrm{R}_{3} \mathrm{Al}$ との反応}

前節であげた基質に対して $\mathrm{R}_{2} \mathrm{AlX}$ のかわりに $\mathrm{R}_{3} \mathrm{Al}$ を 作用させれば新しい炭素一炭素結合生成反応となる ${ }^{5,6)}$ 。 ゲラニルアセテートやネリルアルコールのリン酸エステ ルと $\mathrm{R}_{3} \mathrm{Al}$ とのへキサン中での反応結果を式 (7), (8) に示す。ゲラニル体のとき, $\mathrm{R}_{2} \mathrm{AlX}$ による置換反応ほ どではないが， $\alpha$ 位アルキル化体の選択性はかなり高く， 二重結合の立体配置も完全に保持される。アリル基とア

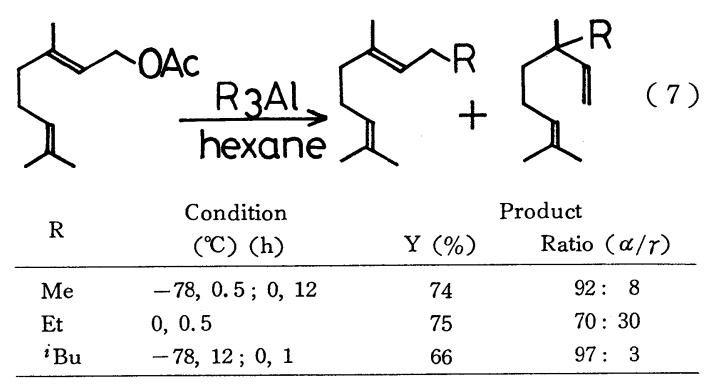

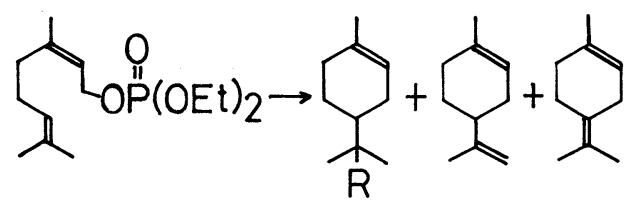

ルキル基とをカップリングさせる反応になるがアリルア ルコールをまず八ロゲン化する必要がなく，エステルは 容易に作れるので合成反応として有利な方法である。ネ ロール体の場合は環化とアルキル化とが同時に進む。

カルベオールのアセテートについて検討した。シス体, トランス体いずれのアセテートから出発しても $\mathrm{Me}_{3} \mathrm{Al}$ との反応に抒いて式（9）に示すようにトランス体が選 択的に得られる。D 化した原料を用いて求めた $\alpha$ 位アル キル化と $r$ 位アルキル化の比はほほ 1 に近い。さらにこ の反応は溶媒 (ヘキサン, $\mathrm{CH}_{2} \mathrm{Cl}_{2}, \mathrm{Et}_{2} \mathrm{O}, \mathrm{THF}$ ) や脱 離基 $\left(\mathrm{OAc}, \mathrm{OP}(\mathrm{O})(\mathrm{OEt})_{2}\right)$ の影響がほとんどない。

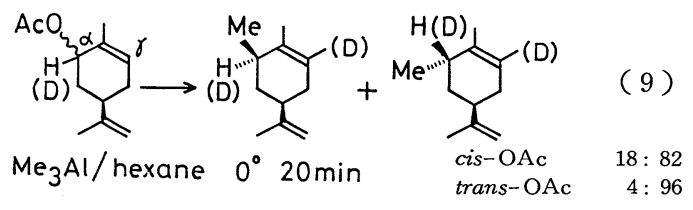

反応の第一段階はアセチル基のカルボニル酸素の $\mathrm{Al}$ への配位である。 $\mathrm{Al}$ に結合した $\mathrm{Me}$ 基は $\mathrm{X}(\mathrm{X}=\mathrm{OAr}$, $\mathrm{SPh}, \mathrm{NHPh})$ に比較してその求核反応性がそしい7)。

$$
\begin{aligned}
& \mathrm{Sub}-\mathrm{O}-\underset{\mathrm{l}}{\mathrm{C}}=\mathrm{O} \ldots . . \mathrm{AlMe}_{3} \\
& \longleftrightarrow \mathrm{Sub}^{\oplus} \mathrm{O}=\underset{\stackrel{\mathrm{I}}{\mathrm{C}}-\mathrm{O} \mathrm{H}_{3}}{\mathrm{C}} \mathrm{O}-\mathrm{Al}^{\ominus} \mathrm{Me}_{3}
\end{aligned}
$$

アセトキシ基を呼びこんでも原系またはアリル転位体に もどるだけである。 $\mathrm{Me}$ 基が移って生成物になるには相 当時間がかかる。アリル陽イオン部分はその閒にもっと も安定な形に変化するものと考えられる。シス体, トラ ンス体いずれのアセテートから出発してもトランス体が 得られ, しかも $\alpha$ 位と $r$ 位アルキル化体の比が 1 に近 い。だから両者に共通な対称的な中間体を考えるのが妥 当である。図 1 に示すような立体配座において $\mathrm{Me}$ 基が

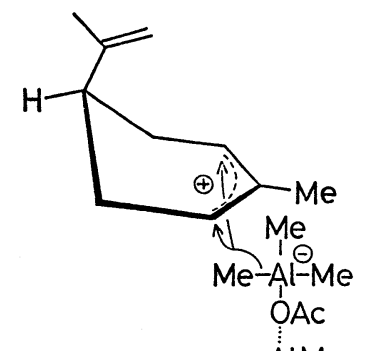

Fig. 1 AllMe3 
イソプロペニル基と反対側からシクロへキセン環を攻撃 するのだろう。

同様な立体化学的知見はアセトキシノルカランについ て得られている。この場合にも式(10)に見るとおりエンド 体，エキソ体いずれから出発しても $\mathrm{Me}_{3} \mathrm{Al}$ との反応で

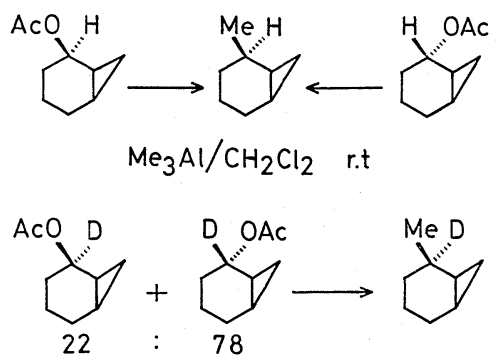

エンド体が $80 \%$ の収率で選択性よく得られる。アセト キシ基の根元の炭素にDを入れた化合物を用いて反応し た結果，Dはもとの位置にとどまることが確認された。 シクロプロパン環の開閉環を伴う反応機構は否定される。 図 2 で示されるような共通の最も安定なカチオンの立体 配座を考え, $\mathrm{Me}$ 基がより立体障害の小さいシス方向か ら移るものと思われる。

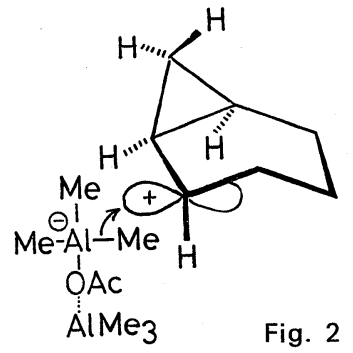

4. $\mathrm{TiCl}_{4}-\mathrm{PhNHMe}$ 系による閉環

ネロールのリン酸エステルをへキサン中 $\mathrm{R}_{2} \mathrm{AlOPh}$ で 処理すると $\mathrm{OPh}$ 置換体ネリルフェニルエーテルが生成 することは 2 節で述べた。ここで溶媒をへキサンから $\mathrm{CH}_{2} \mathrm{Cl}_{2}$ にかえると，イオン対は幾分その密着状態を解 かれて，アリル陽イオン部に末端二重結合の攻撃がおこ

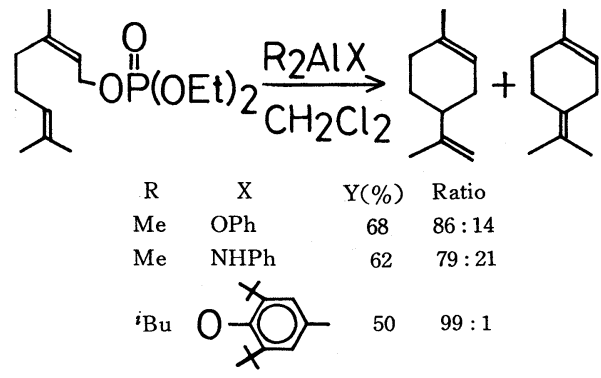

り環化する ${ }^{3,8)}$ 。生成するテルピニル陽イオンから脱プ ロトンがおこり，リモネン，テルピノレン混合物を与え る。しかも式 (11) に示すごとく $\mathrm{R}_{2} \mathrm{~A} 1 \mathrm{X}$ の塩基部 $\mathrm{X}$ は，リモネン，テルピノレンの生成比の分布を決める重 要な役割をしている。つまりテルピニル陽イオンがXの 攻撃により脱プロトンする過程が律速的なのであろうと 推測される。

ネロールの環化に対してアルミニウム反応風以外の新 しい複合反応剂 $\mathrm{TiCl}_{4}-\mathrm{PhNHMe}$ 錯体が有効であるこ とを見いだした ${ }^{9}$ 。 $\mathrm{CH}_{2} \mathrm{Cl}_{2}$ 中 $0{ }^{\circ} \mathrm{C}$ で $\mathrm{TiCl}_{4}$ と $\mathrm{PhNHMe}$ を $1: 1$ で混合することによって得られる。この錯体を 用いればネロールそのものを出発原料として環化をおこ させることができる（式 12 )。テルピニル陽イオンが脱 プロトンするかわりに，塩素陰イオンをとり込んで安定 化する点に特徵がある。 $\mathrm{TiCl}_{4}$ だけではテルピニルクロ リドは得られず，アミンの存在が不可欠である。ゲラニ オールを $\mathrm{TiCl}_{4}-\mathrm{PhNHMe}$ 錯体で処理するとほぼ定量 的にゲラニルクロリドが得られ環化はみられない。出発 物質の立体配置によって生成物が大きく異なる。この点本 方法は $\mathrm{R}_{2} \mathrm{AlX}$ とネロール，ゲラニオールのリン酸エス テルとの反応と共通している。

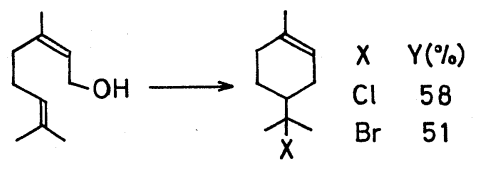

$\mathrm{TiX}_{4}: \mathrm{PhNHMe}(1: 1) \mathrm{CH}_{2} \mathrm{Cl}_{2}\left(-23^{\circ}\right)$ ih

これら環化反応の経路は次のように考えられる。第一 段階はまずアルミニウム反応剤あるいは $\mathrm{TiCl}_{4}-\mathrm{PhNHMe}$ 錯体に強い親和性をもつ酸素原子の配位である。配位体 の生成は速い平衡である。環化に必要な活性化エネルギ 一は低下し，陽イオン部がかなりの自由度をもつときに はスムースにテルピニル陽イオンとなる。第二段階は, 環化後の脱プロトンあるいは塩素陰イオンとり込みであ る。この段階こそ律速段階であり生成物分布を決定する。 図 3 に示すごとくである。

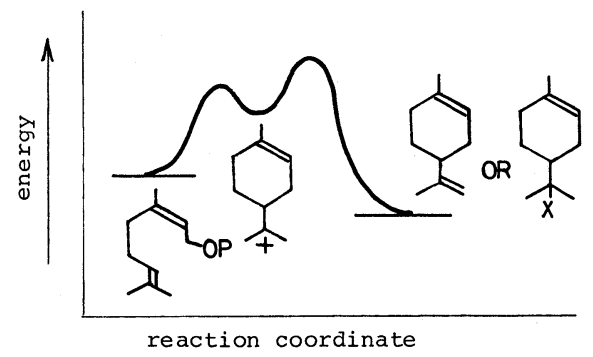

Fig. 3 
Roberts ${ }^{10)}$ 法彼の有機化学教科書の中で酵素反応につ いて説明し，そのモデルとしてクロロメタンと水酸基 $\left(\mathrm{OH}^{\ominus}\right)$ からメタノールを得る反応をとりあげ $\mathrm{I}^{\ominus}$ の触 媒作用について論じている。直接クロロメタンから一段 階の $\mathrm{S}_{\mathrm{N}} 2$ 反応でメタノールに変換するには大きい活性 化エネルギーが必要である。クロロメタンに $\mathrm{I}^{\ominus}$ を $\mathrm{S} \mathrm{N} 2$ 反応させ，まずヨードメタンとする。ついで $\mathrm{OH}^{\ominus}$ と $\mathrm{S}_{\mathrm{N}} 2$ 反応させ,メタノールを得る。目的地一到達するのに一 つの高い山を越えるよりは，この山をより低い二つの山 に分けて楽々と目的地にたどりつく。酵素あるいは触媒 の効能はまさにここにあると述べている。この節で述べ た有機アルミニウム反応剂あるいは $\mathrm{TiCl}_{4}-\mathrm{PhNHMe}$ 錯体を用いる閉環反応は酵素の手口を抽象化し, 実用に 役立てたといえないだろうか。複合反応剂と呼び，ミニ ミニ酵素と名ゔけたいというのはこのような理由からで ある。

ネロール 7 位の $\mathrm{gem}$-メチル基をとり払った化合物に $\mathrm{TiCl}_{4}-\mathrm{PhNHMe}$ 錯体を作用させると Markovnikov 則にのっとった環化が㧍こり， 7 員環生成反応となる (式 13 )。対応する $(E)$ 型アリルアルコールは環化せ<smiles>[R]C(=C)CCC(C)=CCCC</smiles><smiles>[R]C1CC=C(C)CC1</smiles>

$\mathrm{TiX}_{4}-\mathrm{PhNHMe} / \mathrm{CH}_{2} \mathrm{Cl}_{2}-23^{\circ} 1 \mathrm{~h}$

$$
\begin{array}{ccr}
\mathrm{R}=\mathrm{H} & \mathrm{X}=\mathrm{Cl} & \mathrm{Y} \%=65 \\
\mathrm{H} & \mathrm{Br} & 56 \\
\mathrm{Me} & \mathrm{Cl} & 66 \\
\mathrm{Cl} & \mathrm{Cl} & 18
\end{array}
$$

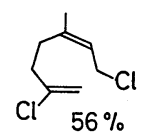

ずそれぞれのアリルハライドを与える。アリルアルコー ルを出発原料として分子内のオレフィン結合への Friedel一 Crafts 型反応としては W.S. Johnson ら ${ }^{11)} の 一$ 連のス テロイド骨格合成の研究が有名である。しかし 7 員環生 成は他に例がなく, 比較的極性の低い溶媒中で楥和な条 件のもと,かなりの収率で 7 員環を与えるこの新方法は今 後の発展が期待できよう。ネズコン合成への応用を式 （14）に示す。ここで苦労したのはクロリドからケトン への変換である。クロリドを $\mathrm{S}$ 反応させようとする試

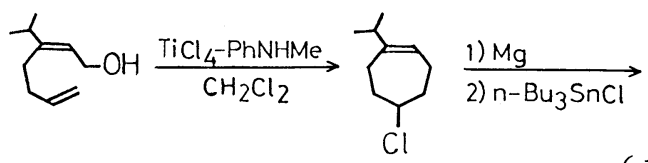
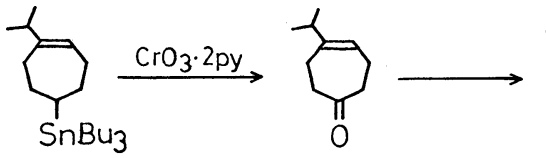<smiles>CC1C=CC(=O)CC1</smiles>

みはすべて失敗に終った。向かい側にある二重結合が $\mathrm{S} \mathrm{N} 2$ 型求核剬の攻撃を妨害するためであろう ${ }^{12)}$ 。クロリ ドを Grignard 反応剤に変換し, $\mathrm{Bu}_{3} \mathrm{SnCl}$ でトラップ

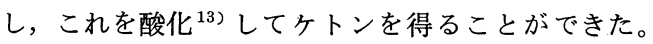

ネロールの環化によって得られたテルピニルクロリド はシリカゲルで処理すると, リモネン, テルピノレンの 混合物を与える。そこであらかじめネロールの適当な位 置に $\mathrm{Me}_{3} \mathrm{Si}$ 基や $\mathrm{Bu}_{3} \mathrm{Sn}$ 基を導入しておき，これらを $\mathrm{TiCl}_{4}-\mathrm{PhNHMe}$ 錯体で処理することを試みた。テル ピニル陽イオンから $\mathrm{Me}_{3} \mathrm{Si}$ 基や $\mathrm{Bu}_{3} \mathrm{Sn}$ 基の脱離が優先 しておこり，式（15）に示すようにリモネンだけを選 択的に得ることができた。

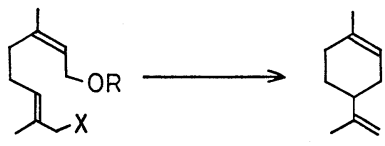

$$
\begin{array}{cllc}
\mathrm{X} & \mathrm{R} & \multicolumn{1}{c}{\text { reagent }} & \mathrm{Y} \% \\
\mathrm{Si} \leftarrow & \mathrm{H} & \mathrm{TiCl}_{4}-\mathrm{PhNHMe}^{-} \mathrm{CH}_{2} \mathrm{Cl}_{2} & 79 \\
\mathrm{Si} \Leftarrow & \mathrm{Ac} & \mathrm{MeAl}\left(\mathrm{OCOCF}_{3}\right)_{2} / \mathrm{hex} & 29 \\
\mathrm{SnBu}_{3} & \mathrm{H} & \mathrm{TiCl}_{4}-\mathrm{PhNHMe}^{-} \mathrm{CH}_{2} \mathrm{Cl}_{2} & 73 \\
\mathrm{SnBu}_{3} & \text { Ac } & \mathrm{MeAl}\left(\mathrm{OCOCF}_{3}\right)_{2} / \text { hex } & 51
\end{array}
$$

アルコールをアセチル化した後 $\mathrm{MeAl}\left(\mathrm{OCOCF}_{3}\right)_{2}$ を 働かせてもリモネンを得ることができるが， $\mathrm{TiCl}_{4}-$ $\mathrm{PhNHMe}$ 錯体を用いる場合に比べて収率は相当低下す る。この方式はテルピノレンの副生皆無という点に特徽 がある。

式 (16) のカラハナエノン合成 ${ }^{14)}$ について少し触れ ておく。最近これに関連して行った実験を式（18）に
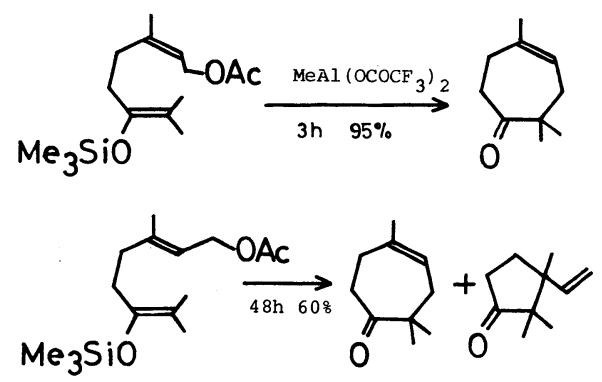

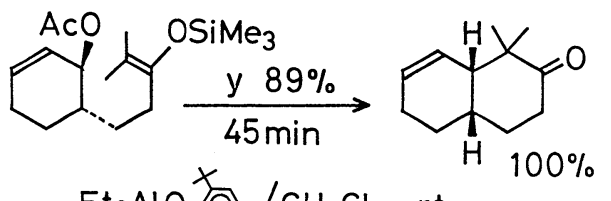


示す ${ }^{15)}$ 。

$\mathrm{MeAl}\left(\mathrm{OCOCF}_{3}\right)_{2}$ は式 (16) では有効であったが, 式（18）の反応に用いると単にシリルエノール部分が 加水分解された形のケトンが主生成物となり環化はおこ らない。商品名で BHT と呼ばれる立体障害の大きいフ エノールから作ったアルミニウム反応剂を用いるとうま く環化する。注目すべきは出発物質の立体配置が反応に 大きく影響する点である。トランス体は短時間でスムー スに反応し, 収率よくしかもシスに融着した双環体だけ を生成する。これに対しシス体は反応が遅く, 収率も低 く, しかも立体異性体混合物を与える。この状況は式 （16）のカラハナエノン合成が短時間できれいに進むの に式 (17) の $(E)$ 異性体では 16 倍も時間がかかり, しかも 7 員環と 5 員環の混合物を低収率で生じるという 事実と酷似している。C $-\mathrm{C} \cdots \mathrm{C}$ 結合は 1.5 重結合だか ら簡単には回転しないとしてもこの差は大きい。おそら く環化後の $\mathrm{Lv}-\ominus \mathrm{AlR}_{2}-\mathrm{B}:\left(\mathrm{Lv}\right.$ : 脱離基, $\ddot{\mathrm{B}}$ は $\mathrm{R}_{2} \mathrm{Al} \ddot{\mathrm{B}}$ という反応剤の塩基部分) の $\mathrm{Si}$ 基への攻撃が律速段階 であり非常に重要だということを示唆しているのだろう。 式（18）のトランス体の場合には図4に示すように, $\mathrm{Lv}-\ominus \mathrm{AlR}_{2}-\ddot{\mathrm{B}}$ の塩基部が $\mathrm{Me}_{3} \mathrm{Si}$ 基を攻撃しやすい立 体的な位置をとる。他方シス体で注この攻撃が立体的に 不可能であるために反応が遅いと考えられる。つまりこ こでも，また $\mathrm{Al}$ の酸性によるアリル陽イオンの生成が 律速ではなくて, イオン対の陰イオン部分 $\mathrm{Lv}-\ominus \mathrm{AlR}_{2}-$ B の塩基としての攻撃が重要な段階であるという考えが 支持される。

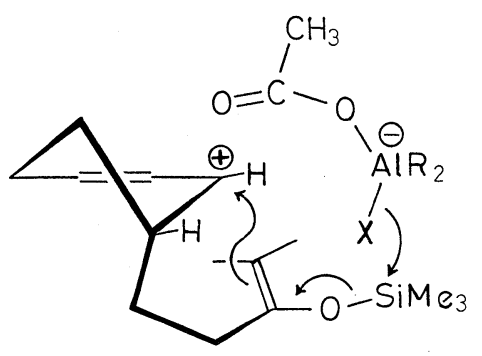

Fig. 4

5. アルミニウムエノラートの生成とアルドール付加 山本尚ら ${ }^{16)}$ は $\mathrm{Et}_{2} \mathrm{AlCl}$ 等モル共存下に $\alpha$-ブロモケト ンを亜鉛末還元してェノラートを生成させることに成功 した。表 1 に示すように低温, 高収率で交差アルドール 体を与える。本反応は Reformatsky 反応にも拡張できる （式 19）。式（20）で $\alpha$ 位反応体が生成することは注目 に価しよう。この $r$-ブロモクロトン酸エステルの反応を
Table 1 Synthesis of $\beta$-hydroxy carbonyl compounds.

\begin{tabular}{|c|c|c|c|}
\hline $\begin{array}{l}\text { Bromo } \\
\text { ketone }\end{array}$ & $\begin{array}{l}\text { Carbonyl } \\
\text { Compound }\end{array}$ & $\begin{array}{l}\text { Temp } \\
\left({ }^{\circ} \mathrm{C}\right)\end{array}$ & $\begin{array}{c}\mathrm{Y} \\
(\%)\end{array}$ \\
\hline & $\begin{array}{l}\mathrm{PhCHO} \\
\left(\mathrm{CH}_{3}\right)_{2} \mathrm{CHCHO}\end{array}$ & $\begin{array}{l}-23 \\
-23\end{array}$ & $\begin{array}{l}97^{\text {a) }} \\
93^{\text {a) }}\end{array}$ \\
\hline $\begin{array}{c}\mathrm{PhCCH}_{\|} \mathrm{Br} \\
\mathrm{O}\end{array}$ & $\begin{array}{l}\left(\mathrm{CH}_{3}\right)_{2} \mathrm{CHCHO} \\
\mathrm{PhCH}=\mathrm{CHCHO} \\
\text { Cyclohexanone }\end{array}$ & $\begin{array}{l}-23 \\
-23 \\
-23\end{array}$ & $\begin{array}{l}92 \\
92 \\
83\end{array}$ \\
\hline & $\left(\mathrm{CH}_{3}\right)_{2} \mathrm{C}=\mathrm{O}$ & r. $t$ & 79 \\
\hline
\end{tabular}

$\mathrm{Zn}, \mathrm{Mg}$ などをそれぞれ単独で使ったとき，エステルの $r$ 位反応体ばかりが生成する。

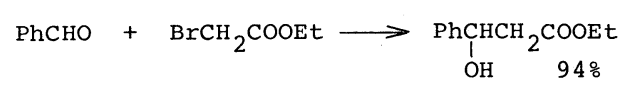<smiles>C=CC(C(=O)OC)C(O)C(O)c1ccccc1</smiles>
$\mathrm{Zn}-\mathrm{CuBr}-\mathrm{Et} \mathrm{A}_{2} \mathrm{AlCl}, \mathrm{THF}, 40 \mathrm{~min}$

$\mathrm{Et}_{2} \mathrm{AlCl}$ は $\mathrm{Zn}$ を活性化しその還元能力を著しく高め ると同時に式 (21) に示す $\mathrm{Zn}$ との協力によって $\mathrm{Al}$ エ ノラートを作り出す。これがアルミニウムエノラートの 反応であるということは DATMP17) を用いる交差アル

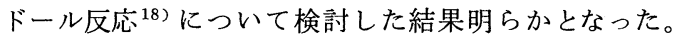
これを述べるに先だってまずDATMP の反応について 簡単に触れておく。

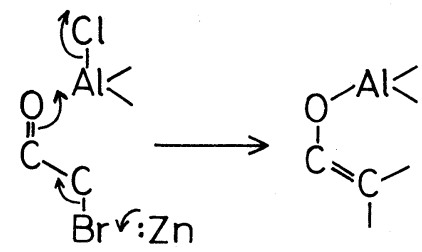

式（22）によって製取されるDATMP反応剂のきわ だった特徴は式（23），（24）に示すようにオキシラン をアリルアルコールに異性化させる反応で観察されてい る。その作用は図 5 によって説明される。オキシラン酸 素にアルミニウムが配位する過程は速い平衡, trivial step である。三置換オキシランの水素側から配位した場 合，その側のアルキル基 $\mathrm{R}^{1} \mathrm{CH}_{2}$ の $\alpha$-プロトンが引き 


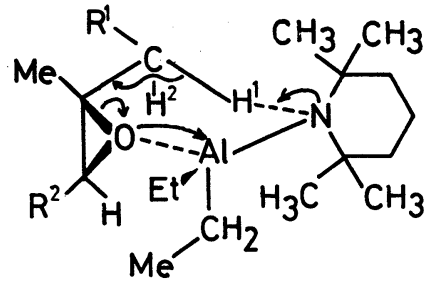

Fig. 5

抜かれる。図 5 のボート型 6 員環で $\mathrm{R}^{1} \mathrm{CH}_{2}$ 基の図示水 素 $\mathrm{H}^{1}$ が引き抜かれて，オレフィンとなる。 $\mathrm{H}^{2}$ が抜けな いのは環平面の下側には強い立体障害があり, $\mathrm{H}^{2}$ の位置

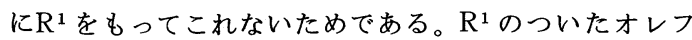
イン結合は必ず $(E)$ 配置となる。テトラメチルピペリ ジドのかわりにジイソプロピルアミドでは $(E) /(Z)$ $1: 1$ の混合物が生成する。図 5 が syn $\mathrm{E} 2 \mathrm{H}$ 型反応であ ることに注意してほしい。

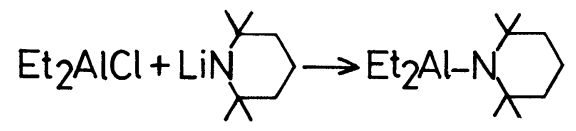<smiles>[R]C=C(C)C([R2])(O)C=[W]</smiles>

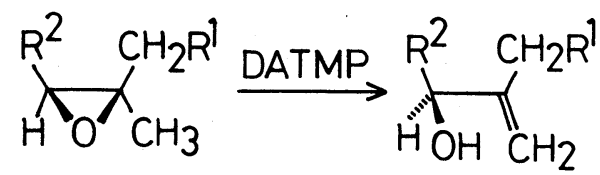

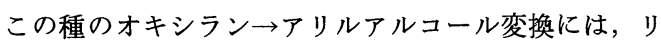
チウムアミドを用いる古い方法のほか多くの方法があ $ろ^{19)}$ 。DATMP のユニークな特性は上記の特異性にあ
る。DATMP はシクロへキセンエポキシドやシクロオ クテンエポキシドとは反応しない。しかしこの「反応し ない」ことこそ特異性, 高選択性の原因であり，「一般 性」と「特異性」という概念は両立しないものであると いうことを強調しておきたい。

$\mathrm{Al}$ はオキシランの酸素をかかえこむ。とたんに目を さました窒素はいちばん具合のよいプロトンを選んで引 き抜く。Al の Lewis 酸としての作用と窒素原子の塩基 としての作用がうまく複合的に衔くことによってアリル アルコールへの変換が syn-E $2 \mathrm{H}$ スキームに従ってスム ースに進行する。

ここでオキシランのかわりにカルボニル化合物をもっ てきたらどうか。同じように 6 員環でカルボニルの $\alpha-$ プロトンを引き抜きアルミニウムエノラートが生成する のではないか（式 25 )。この考えに基づいて DATMP による交差アルドールについて検討を始めた。結果は表 2に示寸通りである。溶媒として種々検討したが THF が最適であった。表中クロトン酸エチルの反応において エステルの $\alpha$ 位反応体ばかりが生成する。これは $\mathrm{Et}_{2} \mathrm{AlCl} /$ $\mathrm{Zn}$ 系による式 (20) の r-ブロモエステルからの生成 物と同じであり, 先の $\mathrm{Et}_{2} \mathrm{AlCl}$ 共存下に $\alpha$-ブロモカル ボニル化合物から亜鉛還元によって得られるエノラート もアルミニウムエノラートであることを示している。本 節で述べた二つの反応によって2-メチルシクロへキ开 ノンから位置選択的にエノラートを作り出すことができ

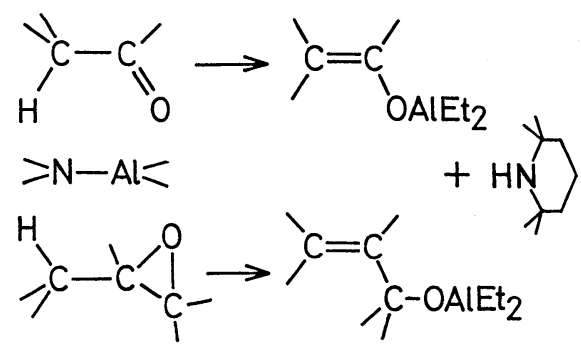

Table 2 Aldolic addition mediated by DATMP.

\begin{tabular}{|c|c|c|c|c|}
\hline \multicolumn{2}{|c|}{$\mathrm{R}^{1} \mathrm{CH}=\mathrm{C}\left(\mathrm{OAlEt}_{2}\right) \mathrm{R}^{2}$} & \multicolumn{2}{|c|}{$\mathrm{R}^{3} \mathrm{COR}^{4}$} & \multirow{2}{*}{$\begin{array}{c}\mathrm{R}_{3}>\mathrm{C}(\mathrm{OH})-\mathrm{CHR}^{1}-\mathrm{COR}^{2} \\
\mathrm{R}^{4}>\mathrm{Y}(\%)(\mathrm{e} / \mathrm{t})\end{array}$} \\
\hline $\mathrm{R}^{1}$ & $\mathrm{R}^{2}$ & $\mathrm{R}^{3}$ & $\mathrm{R}^{4}$ & \\
\hline $\mathrm{H}$ & $\mathrm{OC}\left(\mathrm{CH}_{3}\right)_{3}$ & $\mathrm{Ph}$ & $\mathrm{H}$ & 92 \\
\hline $\mathrm{H}$ & $\mathrm{OC}\left(\mathrm{CH}_{3}\right)_{3}$ & \multicolumn{2}{|c|}{$-\left(\mathrm{CH}_{2}\right)_{5}-$} & 87 \\
\hline $\mathrm{CH}_{2}=\mathrm{CH}$ & $\mathrm{OC}\left(\mathrm{CH}_{3}\right)_{3}$ & $\mathrm{Ph}$ & $\mathrm{H}$ & $68(1 / 1)$ \\
\hline \multicolumn{2}{|c|}{$-\left(\mathrm{CH}_{2}\right)_{4}-$} & $\mathrm{Ph}$ & $\mathrm{H}$ & $78(4 / 5)$ \\
\hline $\mathrm{H}$ & $\mathrm{Ph}$ & $\mathrm{CH}_{3}$ & $\mathrm{CH}_{3}$ & 65 \\
\hline $\mathrm{H}$ & $\mathrm{Ph}$ & \multicolumn{2}{|c|}{$-\left(\mathrm{CH}_{2}\right)_{5}-$} & 63 \\
\hline \multirow{2}{*}{\multicolumn{2}{|c|}{$\begin{array}{l}-\mathrm{CH}_{2} \mathrm{CH}_{2} \mathrm{CH}_{2} \mathrm{CH}\left(\mathrm{CH}_{3}\right)- \\
-\mathrm{CH}_{2} \mathrm{CH}_{2} \mathrm{CH}_{2} \mathrm{CH}\left(\mathrm{CH}_{3}\right)-\end{array}$}} & $\mathrm{Ph}$ & $\mathrm{H}$ & 72 \\
\hline & & $\left(\mathrm{CH}_{3}\right)_{2} \mathrm{CH}-$ & $\mathrm{H}$ & 55 \\
\hline
\end{tabular}




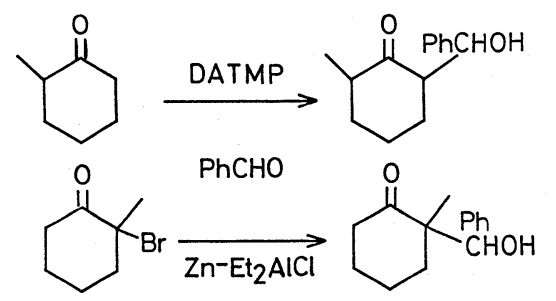

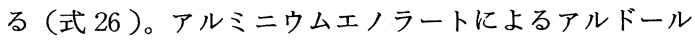
反応については辻二郎教授らの報告 ${ }^{20)}$ も参照いただき たい。

アルドール反応における最近の関心事はエリトロ体, トレオ体の作り分けである ${ }^{21)}$ 。ホウ素のエノラートにお いては $E$ 体， $Z$ 体をうまく作り分ける方法が見いださ れ, これからのエリトロ体，トレオ体が選択性よく得ら れることが報告されている ${ }^{22)}$ 。さらには複雑な天然物へ の応用もなされている ${ }^{23)}$ 。アルミニウムエノラートの場 合にもエノラートの作り分けができればェリトロ，トレ オを選択的に合成できるという可能性は示唆されている が24)，実用の段階には達していない。ここで述べた二つ のアルミニウムエノラートによるアルドール付加におい ても, 残念ながらエリトロ,トレオのほぼ 1: 1 混合物が 得られる。アルミニウムエノラートの宿命かもしれない。

\section{6. $\alpha, \beta$ 不飽和カルボニル化合物への}

\section{1,4 付加とアルドール付加}

$\mathrm{R}_{2} \mathrm{CuLi}$ が $\alpha, \beta$ 不飽和カルボニル化合物に Michael付 加するのは周知のことである ${ }^{25)}$ 。しかしこの際中間に生 成するエノラートをカルボニル化合物でトラップするこ とはあまりうまくいかない26)。 $\mathrm{R}_{2} \mathrm{CuLi}$ のかわりに複合 反応風 $\mathrm{R}_{2} \mathrm{AlX}$ を使えばどうだろうか。i） $\mathrm{R}_{2} \mathrm{AlX}$ を $\beta$ 不飽和カルボニル化合物に Michael 付加させ, ii) 生 ビたアルミニウムエノラートをカルボニル化合物と反応 させてアルドール付加体とする。iii） X $\mathrm{HX}$ として脱 離させる。全体として $\mathrm{C}=\mathrm{C}^{\ominus}-\mathrm{CO}-\mathrm{Y}$ と等価な ものを作り出したことになるだろう（式 $27 ） 。$

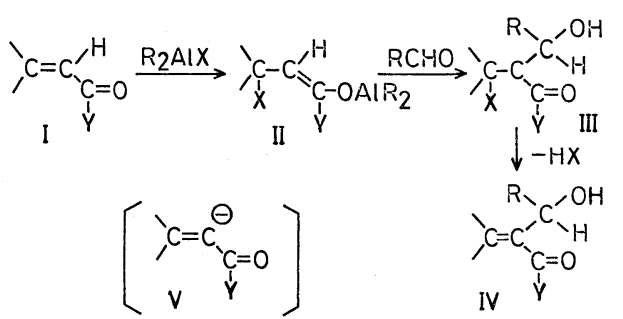

$\mathrm{R}_{2} \mathrm{AlX}$ の塩基部分 $\mathrm{X}$ としては求核性の強いものを選 ばねばならない。種々検討した結果 $\mathrm{SPh}, \mathrm{SeMe}$ 基がよ
Table 3 Reaction between $\alpha, \beta$-unsaturated carbonyl compound and aldehyde by means of $\mathrm{Me}_{2} \mathrm{AlX}$.

\begin{tabular}{l|l|l|c}
\hline $\begin{array}{c}\alpha, \beta-\text { Unsaturated } \\
\text { Carbonyl Compound }\end{array}$ & \multicolumn{1}{|c|}{$\mathrm{X}$} & \multicolumn{1}{|c}{$\begin{array}{c}\text { Aldehyde } \\
\text { RCHO }\end{array}$} & $\begin{array}{c}\text { III } \\
\text { Y (\%) }\end{array}$ \\
\hline 2-cyclohexenone & $\mathrm{SPh}$ & $\mathrm{CH}_{3} \mathrm{CHO}$ & 94 \\
2-cyclohexenone & $\mathrm{SeMe}$ & $\mathrm{CH}_{3} \mathrm{CHO}$ & 77 \\
2-cyclohexenone & $\mathrm{SPh}$ & $\mathrm{CH}_{3}\left(\mathrm{CH}_{2}\right)_{7} \mathrm{CHO}$ & 90 \\
$\mathrm{CH}_{2}=\mathrm{CHCOCH}_{3}$ & $\mathrm{SPh}$ & $\mathrm{CH}_{3} \mathrm{CHO}$ & 60 \\
$2-$ cyclopentenone & $\mathrm{SPh}$ & $\mathrm{HCHO}^{-}$ & 56 \\
$2-$ cyclopentenone & $\mathrm{SPh}$ & $\mathrm{CH}_{3}(\mathrm{CH})_{7} \mathrm{CHO}$ & 76 \\
$\mathrm{CH}_{2}=\mathrm{CHCOOC}_{2} \mathrm{H}_{5}$ & $\mathrm{SPh}$ & $\mathrm{CH}_{3} \mathrm{CHO}$ & 73 \\
\hline
\end{tabular}

い結果を与えた ${ }^{27)}$ 。表 3 に示すとおりである。 $\alpha, \beta$ 不飽 和エステルの場合には $\mathrm{Me}_{2} \mathrm{AlSPh}$ では Michael 付加と エステル基のチオエステル基への変換 ${ }^{28)}$ が競争しておこ りうまくいかない。新しいate complex, $\mathrm{Me}_{3} \mathrm{Al}^{\ominus} \mathrm{SPhLi}{ }^{\oplus}$ を開発することによって，この困難は克服された。第二 段階のアルドール反応に対してはこの場合も THF が最 上の溶媒である。

表中で一例だけ in situ で $\mathrm{PhS}$ 基の脱離がおこってい る。他のものも簡単な操作，つまり酸化とそれにつゔく 脱離反応によって $\mathrm{PhS}$ 基, SeMe 基を除去することが できる ${ }^{29)}$ 。また $\alpha, \beta$ 不飽和カルボニル化合物, $\mathrm{Me}_{2} \mathrm{AlSPh}$, アルデヒドの混合物に work up に先立って $\mathrm{CuCl}_{2}$ と $\mathrm{NaOAc}$ を加えることによりワン・ポットで $\mathrm{PhS}$ 基を除 去することも可能である。

表中 5 行目の反応で得られる化合物自身シクロペンテ ノイドの抗生物質合成の鍵化合物であり ${ }^{30)}$ ，この種の化 合物の有用性を示している。さらにこの反応を合成に応 用する手段として, 得られた $\alpha$-置換 $\alpha, \beta$ 不飽和カルボ ニル化合物に対して二, 三の反応を行った。アルコール をアセチル化した後 $\mathrm{R}_{2} \mathrm{CuLi}$ を作用させれば式 $(28)$ と なる ${ }^{31)}$ 。またアルコールに $\mathrm{CH}_{3} \mathrm{C}(\mathrm{OEt})_{3}$ を反応させて Claisen 転位をおこさせれば，全体として $\alpha, \beta$ 不飽和 カルボニル化合物の $\alpha$ 位， $\beta$ 位でそれぞれ新しい炭素一 炭素結合を作り出す方法となる ${ }^{32)}$ 。
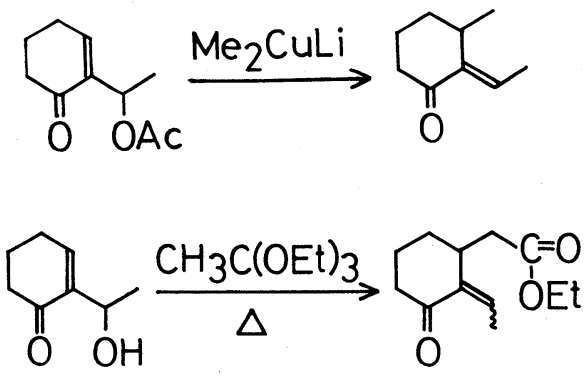
ここで述べた反応は分子内にアルデヒド基をもつ $\alpha$, $\beta$-不飽和カルボニル化合物にも適用でき, 式 ( 30$)$, （31）のごとく，環化反応を行うことができる。スピロ 化合物が高収率で得られ天然物合成にも有効であろう。
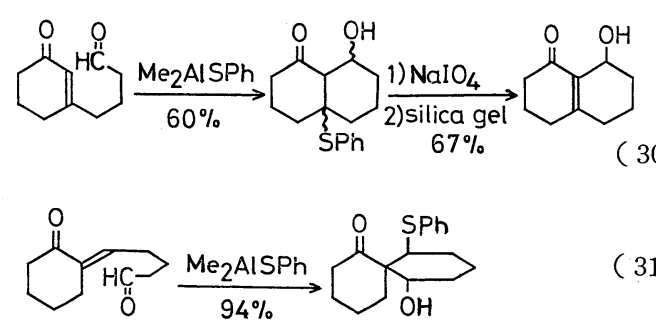

ごく最近, $\mathrm{Me}_{2} \mathrm{AlSPh} や \mathrm{Me}_{2} \mathrm{AlSeMe}$ のかわりに $\mathrm{Et}_{2} \mathrm{AlI}$ を用いれば非常に簡単にしかも一段階で目的の 化合物が得られることがわかった。たとえばシクロへキ セノンとベンズアルデヒドを $\mathrm{CH}_{2} \mathrm{Cl}_{2}$ に溶かしておき, $0{ }^{\circ} \mathrm{C}$ で $\mathrm{Et}_{2} \mathrm{All}$ を加えると Michael 付加, アルドール, $\mathrm{HI}$ の脱離が一挙に扢こり $90 \%$ もの高収率で対応する $\alpha$-置換 $\alpha, \beta$ 不飽和ケトンが得られる ${ }^{33) 。}$

\section{Lewis 酸一還元剂複合系}

第 5 節で触れた $\alpha-$ ブロモカルボニル体 $-\mathrm{Zn}-\mathrm{Et}_{2} \mathrm{AlCl}$ 系を再考してみよう。式（21）に示したようにカルボ ニル酸素に Lewis 酸が配位すると, その LUMO レベル が下るといわれる。そしてこの場合塩基に相当するむの は反応鼡の外にある $\mathrm{Zn}$ である。Zn は電子供給源だか ら塩基と共通点がないともいえない。有機アルミニウム 化合物は亜鉛の酸化剂被膜をはぎとって新鮮な面を露出 させる意味もあるらしい。さらに系内の微量の水を除去 する能力もそなえている。こうしたわけで無機八ライド 系 Lewis 酸が $Z n$ の還元能力をいちじるしく高めるので ある。そのもっとも顕著な例を $\mathrm{CH}_{2} \mathrm{I}_{2}-\mathrm{Zn}-\mathrm{AlMe}_{3}$ 系, $\mathrm{CH}_{2} \mathrm{Br}_{2}-\mathrm{Zn}-\mathrm{TiCl}_{4}$ 系に見ることができる。両者とも $\mathrm{CH}_{2}{ }^{2} \ominus$ 反応種を発生させ，それぞれアルデヒド，ケト ンのカルボニル酸素を $\mathrm{CH}_{2}$ で置換するのに有力な反応 羭となる ${ }^{34}$ 。

$\mathrm{CH}_{2} \mathrm{I}_{2}, \mathrm{Zn}, \mathrm{Me}_{3} \mathrm{Al}$ を室温で混ぜることによって得 られる反応阂にカルボニル化合物を加え数時間反応させ る。結果を表 4 に示す。これらの条件下では $\mathrm{C}=\mathrm{O}$ への攻撃だけがみられ， $\mathrm{C}=\mathrm{C}$ へのメチレン付加つまり Simmons-Smith 反応は全くおこらない。ケトンとの 反応で $\mathrm{Me}_{3} \mathrm{Al}$ を使ったのでは収率は $70 \%$ に満たない。 しかしこの場合 Lewis 酸として $\mathrm{TiCl}_{4}$ を用いれば高収 率を得ることができる。 $\mathrm{TiCl}_{4}$ の場合には $\mathrm{CH}_{2} \mathrm{I}_{2}$ だけ でなく $\mathrm{CH}_{2} \mathrm{Br}_{2}$ でも反応は進行する（表 5)。Wittig 反
Table 4 Reaction of $\mathrm{RCOR}^{\prime}$ with $\mathrm{CH}_{2} \mathrm{I}_{2}-\mathrm{Zn}-\mathrm{Me}_{3} \mathrm{Al}$.

\begin{tabular}{|c|c|c|c|c|}
\hline \multicolumn{2}{|c|}{$\mathrm{RCOR}^{\prime}$} & \multirow{2}{*}{$\begin{array}{l}\text { Temp } \\
\left({ }^{\circ} \mathrm{C}\right)\end{array}$} & \multirow{2}{*}{$\begin{array}{l}\text { Time } \\
\text { (h) }\end{array}$} & \multirow{2}{*}{$\begin{array}{c}\mathrm{RR}^{\prime} \mathrm{C}=\mathrm{CH}_{2} \\
\mathrm{Y}(\%)\end{array}$} \\
\hline $\mathrm{R}$ & $\mathrm{R}^{\prime}$ & & & \\
\hline $\mathrm{Ph}$ & $\mathrm{H}$ & 25 & 1 & 86 \\
\hline $\mathrm{Ph}$ & $\mathrm{Me}$ & 25 & 2 & 67 \\
\hline $\mathrm{PhCH}=\mathrm{CH}-$ & $\mathrm{H}$ & 0 & 1 & 75 \\
\hline $\mathrm{CH}_{3}\left(\mathrm{CH}_{2}\right)_{10}$ & $\mathrm{H}$ & 0 & 4 & 81 \\
\hline $\mathrm{CH}_{3}\left(\mathrm{CH}_{2}\right)_{7}$ & ${ }_{3}\left(\mathrm{CH}_{2}\right)_{2}-$ & 25 & 2 & 62 \\
\hline \multirow{2}{*}{\multicolumn{2}{|c|}{$\begin{array}{c}-\left(\mathrm{CH}_{2}\right)_{11}- \\
(\mathrm{citral})\end{array}$}} & 25 & 6 & 65 \\
\hline & & 25 & 4 & 80 \\
\hline
\end{tabular}

Table 5 Reaction of RCOR' with $\mathrm{CH}_{2} \mathrm{Br}_{2}-\mathrm{Zn}-\mathrm{TiCl}_{4}$

\begin{tabular}{|c|c|c|c|c|}
\hline \multicolumn{2}{|c|}{$\mathrm{RCOR}^{\prime}$} & \multirow{2}{*}{$\begin{array}{l}\text { Temp } \\
\left({ }^{\circ} \mathrm{C}\right)\end{array}$} & \multirow{2}{*}{$\begin{array}{l}\text { Time } \\
\text { (h) }\end{array}$} & \multirow{2}{*}{$\begin{array}{c}\mathrm{RR}^{\prime} \mathrm{C}=\mathrm{CH}_{2} \\
\mathrm{Y}(\%)\end{array}$} \\
\hline $\mathrm{R}$ & $\mathrm{R}^{\prime}$ & & & \\
\hline \multicolumn{2}{|c|}{$\mathrm{CH}_{3}\left(\mathrm{CH}_{2}\right)_{7}-\mathrm{CH}_{3}\left(\mathrm{CH}_{2}\right)_{2}-$} & 25 & 12 & 89 \\
\hline \multicolumn{2}{|c|}{$-\left(\mathrm{CH}_{2}\right)_{11}-$} & 25 & 12 & 80 \\
\hline \multirow{2}{*}{\multicolumn{2}{|c|}{$\begin{array}{r}-\left(\mathrm{CH}_{2}\right)_{6}- \\
\text { (camphor) }\end{array}$}} & 25 & 6 & 83 \\
\hline & & 25 & 40 & 92 \\
\hline \multicolumn{2}{|c|}{ (geranylacetone) } & 25 & 12 & 83 \\
\hline $\mathrm{CH}_{3}\left(\mathrm{CH}_{2}\right)_{10}-$ & $\mathrm{H}$ & 0 & 4 & $55^{\mathrm{a}}$ \\
\hline
\end{tabular}

${ }^{\mathrm{a}} \mathrm{CH}_{3}\left(\mathrm{CH}_{2}\right)_{10} \mathrm{CH}(\mathrm{OH}) \mathrm{CH}(\mathrm{OH})\left(\mathrm{CH}_{2}\right)_{10} \mathrm{CH}_{3}$ were obtained $(24 \%)$

応では好收率が得られないシクロペンタノンやカンファ 一においても良好な結果を与える。向山教授ら ${ }^{35}$ は低原 子価チタンによるカルボニル化合物の還元的二量化反応 を報告している。ケトンを反応相手とする限りこうした 還元体の生成は全く認められない。アルデヒドたとえば ドデカナールの場合には, 還元二量化反応もおこり 1,2 ジオール体がかなり副生する。しかしこの欠点は $\mathrm{Me}_{3} \mathrm{Al}$ を用いることにより解決される。 $\mathrm{Me}_{3} \mathrm{Al}$ と $\mathrm{TiCl}_{4}$ は相 補的であるといえる。

Seyferth $ら^{36)}$ は Simmons-Smith 反応剂を THF 中 で作り, その上澄液に塩化トリメチルスズを作用させて $\mathrm{Me}_{3} \mathrm{SnCH}_{2} \mathrm{I}$ を合成している。これに対し本節で述べた $\mathrm{CH}_{2} \mathrm{I}_{2}, \mathrm{Zn}, \mathrm{Me}_{3} \mathrm{Al}$ の $\mathrm{THF}$ 混合物の上澄液を塩化卜リ メチルスズでトラップするとスズの二つ入った化合物 $\mathrm{Me}_{3} \mathrm{SnCH}_{2} \mathrm{SnMe}_{3}$ が得られた（式 32 )。このことから

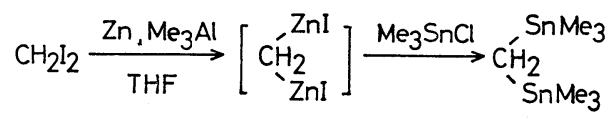

cf.

$\mathrm{CH}_{2} \mathrm{I}_{2} \underset{\mathrm{THF}}{\stackrel{\mathrm{Zn}(\mathrm{Cu})}{\longrightarrow}}\left[\mathrm{ICH}_{2} \mathrm{ZnI}\right] \stackrel{\mathrm{Me}_{3} \mathrm{SnCl}}{\longrightarrow} \mathrm{ICH}_{2} \mathrm{SnMe}_{3}$ 
反応活性種はカルボジアニオン種のジメタル体であると 考えている。

さらに $\mathrm{CCl}_{3} \mathrm{COOEt}-\mathrm{Zn}-\mathrm{Me}_{3} \mathrm{Al}, \mathrm{CHBr}_{2} \mathrm{COOEt}-$ $\mathrm{Zn}-\mathrm{Me}_{3} \mathrm{Al}$ 系化拡張すると式 (33)，(34）に見られ るように $\alpha$-クロロー $\alpha, \beta$-不飽和エステルの合成あるい は Horner-Emmons 型反応となる ${ }^{37) 。 ~}$

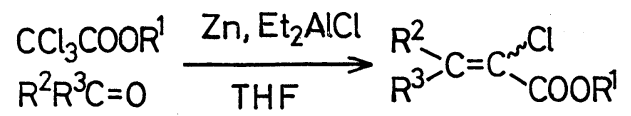

\begin{tabular}{l|c|c|c}
\hline $\mathrm{R}^{1}$ & $\mathrm{R}^{2}$ & $\mathrm{R}^{3}$ & $\mathrm{Y}(\%)$ \\
\hline $\mathrm{Et}$ & $\mathrm{Ph}$ & $\mathrm{H}$ & 48 \\
$\mathrm{Me}$ & \multicolumn{2}{|c|}{$\left(\mathrm{CH}_{3}\right)_{2} \mathrm{C}=\left(\mathrm{CH}_{2}\right)_{5}-$} & 81 \\
$\mathrm{Et}$ & $\mathrm{CH}_{2}\left(\mathrm{CH}_{2}\right)_{2}-$ & $\mathrm{Me}$ & 80 \\
$\mathrm{Me}$ & $\mathrm{Ph}$ & $\mathrm{Me}$ & 82 \\
\hline
\end{tabular}
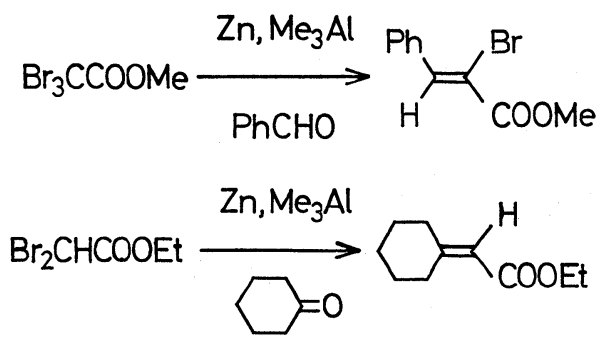

(34)

$\mathrm{Cr}$ (III) と $\mathrm{LiAlH}_{4}$ の系を無水条件でハロゲン化アリ ルに作用させて還元メタル化して >C $=\mathrm{O}$ 基に Grignard 付加させる反応 ${ }^{38)}$ も Lewis 酸一還元剂複合系の典型的 な例である。表 6 亿示す通り位置選択性, 官能基選択性 に特徴がある。この系による八ロゲン化アリルのカップ リング反応に扔いても在来の金属亜鉛と新規反応剤 $\mathrm{Cr}$ (II) との差は歴然としている。

\section{8. $\mathrm{Al}\left(\mathrm{OBu}^{t}\right)_{3}-{ }^{i} \mathrm{BuOOH}$ 系による酸化}

Oppenauer 反応 ${ }^{39}$ はよく知られているようにアルミ ニウムアルコキシドを触媒とする酸化反応である。この 反応においてアルミニウムアルコキシドを酸・塩基複合 反応剂と考えることができる。 $\mathrm{Al}(\mathrm{OR})_{3}$ はアセトンの 酸素をとりこんで錯体を形成する。この配位によって $\mathrm{Al}-\mathrm{O} \mathrm{R}$ は塩基性を呼び覚され, 図 6 のような 6 員環中 間状態においてハイドライドをアセトンに与え自身はケ トンに酸化される。これまでに述べてきた $\mathrm{R}_{2} \mathrm{AlX}$ の反 応では X そのものが塩基として基質を攻撃したのに対 し，この場合塩基部はアルコキシ基からカルボニル化合 物と八イドライドに形を変える。このとき $\mathrm{Al}$ でつかま えられているアセトンが八イドライドを受けとり，酸化 の機能を果している。

最近 Posner ら ${ }^{40)}$ はアセトンのかわりに $\mathrm{CCl}_{3} \mathrm{CHO}$ 用いる方法について報告している。一方著者らは ${ }^{t} \mathrm{BuOOH}$ を酸化剈として使うことを試みて好結果を得た。アリル アルコールからは $\alpha, \beta$ エポキシアルコールが, 第二級 アルコールからはケトンが収率よく得られることがわか った ${ }^{41)}$ 。

ゲラニオールと $\mathrm{Al}\left(\mathrm{OBu}^{t}\right)_{3}$ とを $1: 1.5$ の割合で混ぜ ベンゼンに溶かす。これに ${ }^{t} \mathrm{BuOOH} 2$ 当量を $5^{\circ} \mathrm{C}$ で加 え 3.5 時間攪汼する。無水酢酸, ピリジンで処理し $\alpha, \beta$

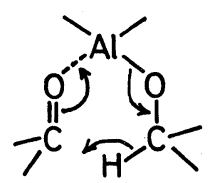

Fig. 6

Table 6 Reaction of allyl halides with carbonyl compounds.

\begin{tabular}{|c|c|c|c|c|}
\hline $\mathrm{RR}^{\prime} \mathrm{CO}$ & Allyl halide & Solvent & \multicolumn{2}{|c|}{ Product } \\
\hline cyclohexanone & allyl bromide & THF & & $(78)$ \\
\hline $\mathrm{PhCHO}$ & & THF & & (94) \\
\hline $\mathrm{PhCHO}$ & & THF & & $(81)$ \\
\hline $\mathrm{PhCHO}$ & allyl chloride & DMF & & $(54)$ \\
\hline & allyl bromide & THF & & $(66$ \\
\hline $\mathrm{OHC} \sim$ & allyl bromide & THF & & $(75)$ \\
\hline
\end{tabular}


エポキシアセテートを $83 \%$ の収率で得た（式 35 )。6,7 位の二重結合がエポキシ化されたものは全く検出されな い。<smiles>CC(=O)OCC12OC1(C)CCC(C(=O)O)=C2C</smiles>

\section{a. $\left({ }^{t} \mathrm{BuO}\right){ }_{3} \mathrm{Al}(1.5),{ }^{\mathrm{t}} \mathrm{BuOOH}(2.0), 5^{\circ} \mathrm{C}, 3.5 \mathrm{~h}$}

\section{b. $A c_{2} \mathrm{O}$, pyridine}

種々のアリルアルコールについてまとめたのが表 7 で ある。Sharpless 法 ${ }^{42}$ によるトレオ体，エリトロ体生成 比も比較のためにあげた。顕著な差が表中 run 2,4,8 に 扔いて認められる。 $\mathrm{VO}(\mathrm{acac})_{2}-{ }^{t} \mathrm{BuOOH}$ 系ではエリ ト口体が選択的に生成するのに対し, $\mathrm{Al}\left(\mathrm{OBu}^{t}\right)_{3}-$ ${ }^{t} \mathrm{BuOOH}$ 系ではトレオ体が主成分である。つまり $\mathrm{E}$ 型 アリルアルコールの場合にバナジウム系とは逆の選択性 を示しており,むしろ $m$-ク口ロ過安息香酸によるエポ キシ化に扔ける選択性と類似している。アリルアルコー ルの立体選択的エポキシ化反応は複雑な天然物合成の鍵

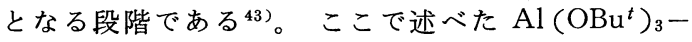
${ }^{t} \mathrm{BuOOH}$ 系によるエポキシ化は合成上有用なものであ ろう。

これらの選択性はエポキシ化における遷移状態におい てアリルアルコールのとりらる立体配座のうちもっとも 有利なものが関与して生じると考えられる。遷移状態に

Table 7 Epoxidation of olefinic alcohols.

\begin{tabular}{|c|c|c|c|c|c|c|}
\hline \multirow{2}{*}{ Run } & \multirow{2}{*}{ Alcohol } & \multicolumn{3}{|c|}{ Product } & \multicolumn{2}{|c|}{$\begin{array}{c}\mathrm{VO}(\mathrm{acac})_{2}- \\
{ }^{t} \mathrm{BuOOH}\end{array}$} \\
\hline & & $\begin{array}{c}\mathrm{Y} \\
(\%)\end{array}$ & $\begin{array}{c}\mathrm{T} \\
\text { (trans) }\end{array}$ & $\begin{array}{c}\mathrm{E} \\
(\mathrm{cis})\end{array}$ & $\begin{array}{c}\mathrm{T} \\
\text { (trans) }\end{array}$ & $\begin{array}{c}\mathrm{E} \\
(\mathrm{cis})\end{array}$ \\
\hline 1 & & 70 & 42 & 58 & 20 & 80 \\
\hline 2 & & 78 & 71 & 29 & 15 & 85 \\
\hline 3 & & 80 & 13 & 87 & 2 & 98 \\
\hline 4 & & 78 & 64 & 36 & 29 & 71 \\
\hline 5 & & 80 & $>99.5$ & $<0.5$ & 86 & 14 \\
\hline 6 & 2-cyclohexenol & 72 & $<0.5$ & $>99.5$ & 2 & 98 \\
\hline 7 & 3 -cyclohexenol & 82 & $<0.5$ & $>99.5$ & 2 & 98 \\
\hline 8 & $\begin{array}{l}(E)-2 \text {-cyclo- } \\
\text { dodecenol }\end{array}$ & 80 & 83 & 17 & 29 & 71 \\
\hline
\end{tabular}

扔いて $\mathrm{C}=\mathrm{C}-\mathrm{C}-\mathrm{O}$ のなす二面角について議論されて いるが ${ }^{44,45)}, \mathrm{Al}$ 系に対しては $m$-ク口ロ過安息香酸に 対するのと同様な二面角 $120^{\circ}$ 付近を考えるのが実験結 果をよく説明できると思われる。

二級アルコールの酸化はほぼ定量的に進行する（式 36 )。これに対し一級アルコールでは反応が遅い。たと えば 1-ドデカノールでは 2 日反応させた後にも原料が $54 \%$ 回収されドデカナールは $13 \%$ しか得られない。 (E)-2-シクロドデセノールを過剩の ${ }^{t} \mathrm{BuOOH}$ 存在下 にベンゼン中加熱還流させるとエポキシ化と二級アルコ ール部位の酸化がひきつづいておこり,一挙にエポキシ ケトンを得ることができる（式 37 ）。なお以上の反応に おいて $\mathrm{Al}\left(\mathrm{OBu}^{t}\right)_{3}$ のかわりに $\mathrm{Me}_{3} \mathrm{Al}$ を用いても同様 の結果が得られる。

$$
\mathrm{R}^{1} \mathrm{R}^{2} \mathrm{CHOH} \underset{\left({ }^{t} \mathrm{BuO}\right)_{3} \mathrm{Al},{ }^{t} \mathrm{BuOOH}}{\mathrm{PhH}, 25^{\circ} \mathrm{C}} \mathrm{R}^{1} \mathrm{R}^{2} \mathrm{C}=\mathrm{O}
$$

\begin{tabular}{c|c|c|c}
\hline $\mathrm{R}^{1}$ & $\mathrm{R}^{2}$ & time (h) & $\mathrm{Y}(\%)$ \\
\hline $\mathrm{Ph}$ & $\mathrm{Me}$ & 6 & 90 \\
$\mathrm{CH}_{3}\left(\mathrm{CH}_{2}\right)_{5}-$ & $\mathrm{Me}$ & 12 & $100^{\mathrm{a}}$ \\
$-\left(\mathrm{CH}_{2}\right)_{11}-$ & 18 & 85 \\
\hline ( & 15 & 85 \\
\hline
\end{tabular}

a. by glpc

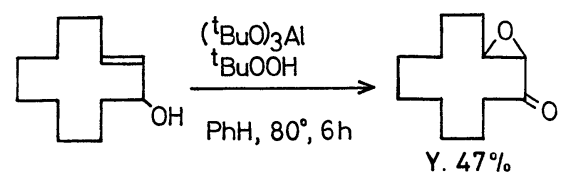

一般にアルミニゥムを用いる酸化反応の利点として多 くの官能基が inert であるということがあげられる。こ こで述べた $\mathrm{Al}\left(\mathrm{OBu}^{t}\right)_{3}-{ }^{t} \mathrm{BuOOH}$ 系における酸化条 件下に掠いて，アセチレン，八ロゲン化物，エーテル， アセタールなどは不活性でほとんどが回収される。穏や かな条件下で進行するので有利な方法といえよう。

反応機構については次のように考える。ベンゼン中， $\mathrm{Al}\left(\mathrm{OBu}^{t}\right)_{3}$ とアルコールを混ぜるとまずアルコールと ${ }^{t} \mathrm{BuO}$ 基の交換がおこり図 7 の (A) の形となる。 $\mathrm{Me}_{3} \mathrm{Al}$ とアルコールを混ぜた場合にはすみやかにメタンガスが 発生し，(A）となる。次に ${ }^{t} \mathrm{BuOOH}$ 加えるともう一 度交換あるいはメタンガスの発生を伴ってアリルアルコ ールの場合には (B), 二級アルコールの場合には (C) となる。（C）において Al は Lewis 酸として働き 1 の 酸素原子をひきつける。この酸素の配位により酸素一酸 


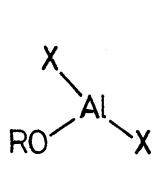

(A)

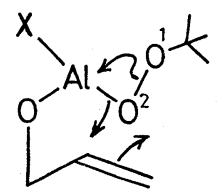

(B)

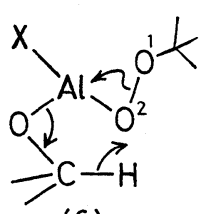

(C)

$$
X={ }^{t} \mathrm{BuO}-\text { or } \mathrm{Me}
$$

Fig. 7

素の結合は分極し 2 の酸素原子は求電子攻撃をおこしや すくなる。そして $\mathrm{Al}-\mathrm{O}-\mathrm{R} の \alpha$ 水素をハイドライド イオンとしてひきぬきカルボニル化合物をあとに残す。

\section{9. おわりに}

\section{酸・塩基複合反応剂としての有機アルミニウム化合物} に焦点をあて，いくつかの反応の開拓を進めてきた。そ の中で得たものはたとえば Zn の共存下にアルミニウム 化合物を使うというちょっとした工夫で従来の反応形式 を一新することができたということである。異種金属を 「複合的」に使うということも今後の検討に価する。要 はアルミニウムに限らず広い視野に立って反応剤のデザ インに意を用い，ハンドメードの反応阂を目的に合わせ て工夫するという楽しみが有機合成に加わってきたとい うことだろう。

（昭和 54 年 11 月 26 日受理）

\section{文献}

1) 野崎 一, 化学と薬学の教室別巻. LIFECHEM, 第 2 号, 1 (1979); 日本化学会第 38 秋季年会, $2 \mathrm{G} 09$ (1978) 名古屋

2）大塚斎之助ら編, 化学の領域増刊 117 号, 金属の 特性を活かした新しい有機合成反応, p. 191 (1977)；日本化学会 (芝 哲夫) 編, 化学総説 19 , 新しい有機合成反応 p. 45 (1978)

3) Y. Kitagawa, S. Hashimoto, S. Iemura, H. Yamamoto, H. Nozaki, J. Am. Chem. Soc..,98, 5030 (1976)

4) S. Ozawa, A. Itoh, K. Oshima, H. Nozaki, Tetrahedron Lett., 1979, 2909

5) S. Hashimoto, Y. Kitagawa, S. Iemura, H. Yamamoto, H. Nozaki, ibid., 1976, 2615

6) A. Itoh, K. Oshima, S. Sasaki, H. Yamamoto, T. Hiyama, H. Nozaki, ibid., 1979, 4751

7) 非常に激しい条件下での $\mathrm{Me}_{3} \mathrm{Al}$ と三級アルコー ル, ベンジルアルコール，フェニルケトンなどの 反応が知られている。

a) D. W. Harney, A. Meisters, T. Mole, Aust. J. Chem., 27, 1639 (1974)

b) A.Meisters, T. Mole, ibid., 27, 1655, 1665 (1974) ; J. Chem. Soc. Chem. Comm., 1972, 595 c) R. G. Salomon, J. K. Kochi, J. Org. Chem., 38, 3715 (1973)

d) A. Basha, S. Weinreb, Tetrahedron Lett.,1977, 1465

8）ネリルホスフェートの加水分解については次の報 告がある。

C. A. Bunton, O. Cori, D. Hachey, J.P. Leresche, J. Org. Chem., 44, 3238 (1979)

9) T.Saito, A. Itoh, K. Oshima, H. Nozaki, Tetrahedron Lett., 1979, 3519

10) J.D. Roberts, R. Stewart, M. C. Caserio, "Organic Chemistry", p. 493, W. A. Benjamin Inc., New York 1971

11) P. A. Bartlett, W.S. Johnson, J. Am. Chem. Soc., 95, 7501 (1973) ; P. A. Bartlett, J. I. Brauman, W. S. Johnson, R. A. Volkmann, ibid., 95, 7502 (1973)

12) S. J. Rhoads, J. M. Watson, J. G. Kambouris, ibid., 100, 5151 (1978)

13) W.C.Still, ibid., 99, 4836 (1977)

14) S. Hashimoto, A. Itoh, Y. Kitagawa, H. Yamamoto, H. Nozaki, ibid., 99, 4192 (1977)

15) A. Itoh, K. Oshima, H. Nozaki, Bull. Chem. Soc. $J p n$., 印刷中

16) K. Maruoka, S. Hashimoto, Y. Kitagawa, H. Yamantoto, H. Nozaki, J. Am. Chem. Soc., 99, 7705 (1977)

17）佐藤俊夫, 化学と工業, 32, 795 (1979); A. Yasuda, S. Tanaka, K. Oshima, H. Yamamoto, H. Nozaki, J. Am. Chem. Soc., 96, 6513 (1974) ; S. Tanaka, A. Yasuda, H. Yamamoto, H. Nozaki, ibid., 97, 3252 (1975) ; A.Yasuda, H. Yamamoto, H. Nozaki, Bull. Chem. Soc. Jpn., 52, 1705, 1752 (1979)

18) H. Nozaki, K. Oshima, K. Takai, S. Ozawa, Chem. Lett., 1979, 379

19) A.C. Cope, G. A. Berchtold, P. E. Peterson, S. H. Sharman, J. Am. Chem. Soc., 82, 6370 (1960) ; J. K. Crandall, L. C. Lin, ibid., 89, 4526, 4527 (1967) ; C.L. Kissel, B. Rickborn, J. Org. Chem., 37, 2060 (1972); S. Murata, M. Suzuki, R. Noyori, J. Am. Chem. Soc., 101, 2738 (1979)

20) J.Tsuji, T. Mandai, Tetrahedron Lett., 1978, 1817 ; J. Tsuji, T. Yamada, M. Kaito, T. Mandai, ibid., 1979, 2257

21) W. A. Kleschick, C. T. Buse, C. H. Heathcock, J. Am. Chem. Soc., 99, 247 (1977); C. T. Buse, C. H. Heathcock, ibid., 99, 8109 (1977); A. I. Meyers, P. J. Reider, ibid., 101, 2501 (1979)

22) D. A. Evans, E. Vogel, J. V. Nelson, ibid., 101, 6120 (1979) ; S. Masamune, S. Mori, D. V. Horn, D. W.Brooks, Tetrahedron Lett., 1979, 1665 ; M. Hirama, S. Masamune, ibid., 1979, 2225 ; D. V. Horn, S. Masamune, ibid., 1979, 
2229. ケイ素のエノラートの $(E),(Z)$ の作り分 けについては, E. Nakamura, K. Hashimoto, I. Kuwajima, Tetrahedron Lett., 1978, 2079

23) M. Hirama, D. S. Garvey, L. D. L. Lu, S. Masamune, ibid., 1979, 3937 ; T. Nakata, G. Schmid, B. Vranesic, M. Okigawa, T.S.Palmer, Y.Kishi, J. Am. Chem. Soc., 100, 2933 (1978) ; T. Fukuyama, K. Akasaka, D. S. Karanefsky, C. L. J. Wang, G. Schmid, Y.Kishi, ibid., 101, 262 (1979)

24) E. A. Jeffery, A. Meisters, T. Mole, J. Organomet. Chem., 74, 365 (1974) ; idem, ibid., 74, 373 (1974)

25) G.H.Posner, Organic Reactions., 19, 1 (1972)

26) G. H. Posner, J. J. Sterling, C. E. Whitten, C. M. Lentz, D. J. Brunelle, J. Am. Chem. Soc., 97, 107 (1975)

27) A. Itoh, S. Ozawa, K. Oshima, H. Nozaki, Tetrahedron Lett., 21, 361 (1980)

28) T. Cohen, R. E. Gapinski, ibid., 1978, 4319

29) P.A.Grieco, M. Miyashita, J. Org. Chem., 40, 1181 (1975) ; H. J. Reich, J. M. Renge, I. L. Reich, J. Am. Chem. Soc., 97, 5434 (1975)

30) S. J.Branca, A. B. Smith, III, ibid., 100, 7767 (1978)

31) T. Hiyama, A. Kanakura, H. Yamamoto, H. Nozaki, Tetrahedron Lett., 1978, 3051

32) L. Ghosez, M. Vandewalle, in "Stereoselective Synthesis of Natural Prodıcts", W. Bartmann, E. Winterfeldt eds., Excerpta Medica,

Amsterdam-Oxford, 1979, p. 93, p. 130
33) S. Ozawa, A. Itoh, K. Oshima, H. Nozaki, 日本 化学会第 41 春季年会, 3 R 24 (1980) 大阪

34) K. Takai, Y.Hotta, K. Oshima, H. Nozaki, Tetrahedron Lett., 1978, 2417

35) T.Mukaiyama, T.Sato, J.Hanna, Chem. Lett., 1973, 1041

36) D. Seyferth, S. B. Andrews, J. Organomet. Chem., 30, 151 (1971)

37) K. Takai, K. Oshima, H. Nozaki, Bull. Chem. Soc. Jpn., 印刷中

38) Y. Okude, S. Hirano, T. Hiyama, H. Nozaki, J. Am. Chem. Soc., 99, 3179 (1977); Y.Okude, T. Hiyama, H. Nozaki, Tetrahedron Lett., 1977, 3829

39) C.Djerassi; Org. Reactions., 6, 207 (1951)

40) G. H. Posner, R. B.Perfetti, A. W. Runquist, Tetrahedron Lett., 1976, 3499

41）高井和彦, 大嶌幸一郎，野崎 一，第 26 回有機 金属討論会 B 102 ; Tetrahedron Lett., 印刷中

42) K. B.Sharpless, R. C. Michaelson, J. Am. Chem. Soc., 95, 6136 (1973)

43) S. Danishefsky, M. Hirama, K. Gombatz, H. Harayama, E. Berman, P. Schuda, ibid., 100, 6536 (1978) ; S. Tanaka, H. Yamamoto, H. Nozaki, K. B. Sharpless, R. C. Michaelson, J. D. Cutting, ibid., 96, 5254 (1974)

44) T.Itoh, K. Jitsukawa, K. Kaneda, S. Teranishi, ibid., 101, 159 (1979)

45) B.E. Rossiter, T.R. Verhoeven, K.B.Sharpless, Tetrahedron Lett., 1979, 4733

\section{お 知 ら せ}

1979 年 1 月より報文, ノートの Synopsis 化を実施 致しております。乙れに伴う新料金([第 37 巻第 1 号」 揭載分から適用)は下記の通りです。

掲載された抄報の原報(マイクロフィッシュ)拈よび そのコピーを希望される方は規定の代金を添えて（現 金書留，または郵券）打申し込み下さい。

$$
\text { 記 }
$$

(0) 投稿料

\section{0,000 円}

（抄報の別刷 50 部，原報のマイクロフィッ シュとそのコピー（B 5 判）各 1 部を含む)

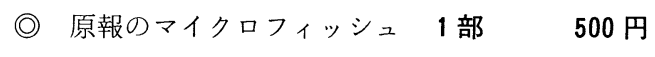

() 原報のコピー（B 5 判） 1ページ* 50 円 [前金，郵送料込み]

（＊原報のページ数は抄報に記載されています。 国外宛航空便は別途取扱います。)

なお，「投稿規定」，「原稿執筆の手引」は 1 月号に，抄 報の “ひな型” は昨年 (第 37 巻) に数報掲載されてお りますので，で投稿の際はこれらをご参照下さい。 